\title{
KAJIAN KRITIS DAMPAK PERKEMBANGAN PARIWISATA TERHADAP EKSISTENSI BUDAYA SUNDA DI KOTA BANDUNG
}

\author{
CRITICAL STUDY OF IMPACT TOURISM DEVELOP MENT \\ TO THE EXISTENCE OF SUNDANESE CULTURE IN BANDUNG
}

\author{
Bambang Sapto Utomo \\ Sukarno Wibowo \\ Harry Soeparman \\ Sekolah Tinggi Pariwisata Bandung \\ Jl. Dr. Setiabudi No. 186 Bandung \\ e-mail:karno_wib@yahoo.com
}

\begin{abstract}
Abstrak
Dewasa ini pariwisata di Kota Bandung terus berkembang dan menunjukkan kontribusinya dalam menyejahterakan masyarakat. Kecenderungan perkembangan pariwisata sekarang ini tidak merujuk pada pelestarian nilai-nilai budaya Sunda, melainkan hanya terkonsentrasi pada industri ekonomi kreatif. Permasalahan ini tentunya dapat mengancam keberadaan pariwisata budaya di mana identitas budaya Sunda pada sektor pariwisata di Kota Bandung mulai ditinggalkan. Penelitian ini bertujuan mengetahui bagaimana dampak perkembangan pariwisata terhadap budaya Sunda di Kota Bandung. Metode penelitian ini menggunakan kualitatif deskriptif. Penulis berusaha mengembangkan konsep dan menghimpun fakta dengan cermat mengenai permasalahan eksistensi budaya Sunda. Teknik pengumpulan data dalam penelitian ini terdiri dari observasi, kajian dokumentasi dan wawancara. Hasil penelitian menjelaskan bahwa perkembangan pariwisata di Kota Bandung berdampak pada melunturnya pariwisata bernuansa nilai budaya Sunda. Eksistensi budaya Sunda sebagai nilai-nilai yang harus dilestarikan kian kurang dihormati pada sisi esensi sejarah. Hal ini ditandai ketika beberapa pagelaran Sunda tidak lagi menyentuh pemahaman pada nilai-niai yang terkandung pada budaya Sunda. Pagelaran hanya bersifat formalitas, seremonial, dan bermotif ekonomi.
\end{abstract}

Kata kunci: pariwisata, budaya Sunda, Bandung.

\begin{abstract}
Tourism in Bandung continues to grow today and show the contribution to the development of social welfare. However, the development of tourism in Bandung focused on the creative industries, while the Sundanese cultural values tend to be ignored. The main purpose of this research is to determine the impact of tourism development to Sundanese culture in Bandung. This research used descriptive qualitative method, that author are tried to develop concepts and gather facts about Sundanese culture in tourism. Data collection techniques in this research consisted of observation, documentation review, and interviews. The results of this research explains that the development of tourism in Bandung impacted to faded Sudanese cultural values in tourism. On the essence of history, the existence of Sundanese culture as values that should be preserved to be less respected. Indicators of declining respect to the Sundanese culture is the lack of understanding on cultural values which contained in a Sundanese arts performances. Sundanese arts performances just a formality, ceremonial and economically motivated.
\end{abstract}

Keywords: tourism, Sundanese culture, Bandung. 


\section{A. PEN DAHULUAN}

Pengembangan dan pemanfaatan potensi pariwisata sebagai salah satu industri merupakan hal subtansi bagi beberapa negara di dunia sebagaimana halnya Indonesia. Pada sisi ini sektor pariwisata pada realitasnya masih dijadikan sektor andalan dalam rangka pembangunan ekonomi negara, hal ini sebagaimana pendapat Sandeep dan Vinod (2014: 1) yang menjelaskan bahwa "Today tourism has been emerged as socioeconomic giant at global regional and national level." Pembangunan sektor pariwisata yang dilaksanakan selama ini ternyata telah mampu meningkatkan perekonomian serta meningkatkan kesejahteraan sebagian masyarakat, baik itu secara regional maupun nasional. Fenomena ini menjelaskan bahwa pariwisata sudah diakui sebagai industri terbesar abad ini, dilihat dari berbagai indikator, seperti sumbangan terhadap pendapatan dunia dan penyerapan tenaga kerja (Pitana dan Gayatri, 2005: 54). Perkembangan ini menunjukan bahwa pariwisata sangat dinamis dan sangat dipengaruhi oleh beberapa faktor seperti ekonomi, politik, sosial, lingkungan dan perkembangan teknologi.

Jenkins (1998: 52-53) menjelaskan bahwa "The reasons behind government support for the tourism industry are; (1) Historically, tourism has a higher growth rate than international trade in general; (2) tourism provides hard currency for developing countries; (3) there are no tariff barriers to international tourism; (4) it is a labor-intensive industry; and (5) there is often an availability of natural and cultural resources for developing international tourist attractions". Tingginya potensi sektor pariwisata pada nyatanya begitu identik dengan nilai ekonomi, bahkan yang terjadi ketika pariwisata sebagai upaya untuk menciptakan sektor ekonomi unggulan. Adapun hal ini dipertegas oleh Petrevska (2012: 1) yang mengatakan "as one of the greatest sources for development, tourism is detected by many undeveloped and developing countries as the only way-out for economic prosperity".

Sebagai contoh pentingnya fungsi pariwisata dijelaskan pada kajian Chancharat (2011: 341) yang menjelaskan bahwa "Economists emphasize the economic effects of tourism on the economy. The speedy growth of tourism causes an increase in household incomes and government revenues through multiplier effects, improvements in the balance of payments, and growth in the number of tourism-promoted government policies. As such, the development of tourism has usually been considered a positive contribution to economic growth. Para ekonom menekankan efek ekonomi pariwisata terhadap perekonomian suatu daerah pariwisata. Pertumbuhan cepat dari pariwisata menyebabkan peningkatan pendapatan rumah tangga dan pendapatan pemerintah melalui efek multiplier, perbaikan dalam neraca pembayaran, dan pertumbuhan jumlah pariwisata dipromosikan melalui kebijakan pemerintahan.

Perkembangan pariwisata di Indonesia dewasa ini menunjukkan perkembangan yang cukup baik, hal tersebut khususnya dapat dilihat dari pertumbuhan jumlah turis yang berkunjung ke daerah-daerah Indonesia. Jumlah kunjungan wisatawan mancanegara ke Indonesia pada Desember 2013 mencapai 860,7 ribu atau naik 12,22 persen dibandingkan jumlah kunjungan wisman pada Desember 2012 sebanyak 767,0 ribu. Begitu pula jika dibandingkan dengan November 2013, jumlah kunjungan wisatawan mancanegara pada Desember 2013 naik sebesar 6,59 persen (BPS, 2014: 1). Fakta ini menunjukkan bahwa pariwisata Indonesia sesungguhnya memiliki potensi wisata yang luar biasa dan memiliki nilai strategis dalam pengembangan ekonomi masyarakat.

Sebagaimana yang telah diketahui terdapat beberapa potensi pariwisata yang 
dimiliki Indonesia, seperti keragaman budaya, tersedianya sumber daya alam, hayati dan bentuk geologi yang bervariasi, menjadikan Indonesia sebagai salah satu negara di dunia yang memiliki daya tarik lengkap bagi turis untuk berkunjung. Sisi ini mendeskripsikan terdapat nilai lebih untuk mengembangkan potensi pariwisata ke dalam struktur yang baik seperti pemanfaatan perkembangan pariwisata tersebut sebagai cara dan peluang peningkatkan eksistensi keragaman budaya di Indonesia yang berlandasan ekonomi/kesejaheraan bersama.

Penjelasan sisi budaya, telah dikemukaan oleh Graburn (dalam Sandeep dan Vinod, 2014: 2) bahwa "Culture or civilization is complex to define but it can be observed as the amalgamate of norm, faith, belief, dance, music handicraft, handloom, sculptures, paintings, art, moral low, custom, traditions and other capabilities and habits acquired by man as a member of society". Pola pemikiran dari penggambaran budaya atau peradaban pada prinsipnya berkaitan dengan penggabungan norma, iman, keyakinan, tari, kerajinan musik, patung, lukisan, seni, rendah moral, adat, tradisi dan lainnya. Hal tersebut merupakan kemampuan dan kebiasaan yang diperoleh oleh manusia sebagai anggota masyarakat. Berdasarkan hal tersebut, eksistensi budaya perlu diciptakan sebagai pengembangan dari manfaat pariwaisata selain ekonomi.

Berdasarkan pendapat Silberberg (1995: 363) menjelaskan bahwa "Cultural tourism, which includes cultural heritage tourism as a part, is defined as visits by people from outside the host community motivated wholly or partly by interest in historical, artistic, scientific or lifestyle/ heritage offerings of a community, region, group or institution". Selanjutnya wisata budaya yang meliputi pariwisata warisan budaya sebagai bagian, tentunya berhubungan dengan kunjungan oleh orang-orang dari luar masyarakat setempat, baik itu termotivasi seluruhnya atau sebagian oleh kepentingan dalam sejarah, seni, ilmu pengetahuan atau gaya hidup/warisan persembahan sebuah komunitas, wilayah, kelompok atau lembaga. Berkaitan dengan ini, Du Cros (2001; 165) mengemukakan bahwa "This definition recognizes that the motivation of visitors to experience culture in some way, and this feature separates cultural tourism from other forms of tourism". Terdapatnya pengakuan bahwa motivasi pengunjung untuk berwisata bertujuan untuk menyelami budaya dalam beberapa cara, dan fitur ini memisahkan wisata budaya dari bentuk-bentuk pariwisata.

Konsepsi dari pariwisata budaya merupakan interaksi antara wisatawan dan masyarakat lokal karena kekuatan tarik budaya di tujuan yaitu budaya dan nilainilai sosial termasuk elemen berwujud dan tidak berwujud budaya. Ritchie dan Zins (dalam Sandeep dan Vinod, 2014: 2) menjelaskan bahwa "Have acknowledged the twelve cultural essentials which pull tourists at the destinations. In brief these elements are the historical monuments, the art, architecture, handicrafts, the traditions, the gastronomy, the leisure activities, and the dress. They also identified the educational system and the religions, faith, language, sculptures. In modern years there have been increases in domestic and international tourism for the purpose of expressing another type of culture." Dengan demikian, budaya sesungguhnya dapat menarik wisatawan ke tempat tujuan (sebagaimana yang diinginkan). Unsur-unsur ini adalah monumen bersejarah, seni, arsitektur, kerajinan, tradisi, gastronomi, kegiatan rekreasi, dan gaun. Mereka juga mengidentifikasi sistem pendidikan dan agama, iman, bahasa, patung dalam kajian daya tarik tersebut. Selanjutnya pendapat tersebut menjelaskan bahwa dalam beberapa tahun telah terjadi peningkatan di bidang pariwisata domestik dan mancanegara dengan tujuan untuk mengungkapkan jenis lain dari manfaat budaya. Adapun hal ini memperlihatkan bahwa pariwisata budaya telah menjadi 
salah satu elemen dasar yang menarik wisatawan untuk tujuan tertentu.

Penjelasan pariwisata budaya dikemukakan juga Hughes (dalam Liu dan Lin, 2011: 364) yang menyatakan bahwa "Further advantage is that the relationship between culture and tourism is widely regarded as mutually beneficial. It is claimed, for instance, that it creates extra revenue streams for both and, as a consequence, sustains and enhances cultural resources that otherwise might disappear". Struktur pariwisata yang dinamis dapat memberikan keuntungan ketika hubungan antara budaya dan pariwisata secara luas dianggap sebagai aspek yang saling menguntungkan. Hal ini dianggap bahwa pariwisata dan budaya dapat menciptakan aliran pendapatan tambahan untuk keduanya, ini akan menepis kekhawatiran terhadap eksistensi budaya yang kian menurun.

Selanjutnya Kapodini-Dimitradi (dalam Liu dan Lin, 2011: 364) mengemukakan bahwa "Also argued that cultural tourism is seen by many policy makers as a means of developing „quality tourism" and attracting high-spending consumers. The third advantage of developing cultural tourism is for spreading tourism both spatially and temporally, because it is relatively independent of the seasons, and like other forms of special-interest tourism it can prompt people to visit areas off the wellbeaten tourist paths. Ini memperlihatkan bahwa pariwisata budaya dapat dipandang oleh banyak pembuat kebijakan sebagai sarana untuk mengembangkan pariwisata berkualitas dan menarik konsumen/turis untuk lebih berbelanja. Selanjutnya keuntungan mengembangkan pariwisata budaya adalah untuk menyebarkan pariwisata baik secara spasial dan temporal, karena relatif independen dari musim dan seperti bentuk lain dari pariwisata minat khusus itu dapat mendorong orang untuk mengunjungi daerah-daerah dari jalur wisata.
Hal yang menarik di mana perkembangan pariwisata di Indonesia tidak serta merta dapat membangun atau meningkatkan potensi dari ketertarikan wisata budaya, kenyataan yang berkembang di daerah-daerah termasuk di Kota Bandung yaitu nilai budaya tidak terlalu dimanfaatkan baik itu melalui potensi atau pengembangan pariwisata pada sesuatu yang saling berhubungan. Realitas yang terjadi ketika perkembangan pariwisata di Kota Bandung lebih terkonsentrasi kepada sektor ekonomi perdagangan sebagaimana pendirian pusatpusat pembelanjaan factory outlet yang tersebar di pusat-pusat kota. Permasalahan ini menunjukkan bahwa identitas budaya Sunda yang sebelumnya berkaitan dengan Kota Bandung terus tergusur pada sektor ekonomi perdagangan yang kurang dipadukan dengan nilai-nilai budaya Sunda.

Dilematis pembangunan pariwisata dengan pembangunan kebudayaan diukur dari pengertian pariwisata dipersepsikan sebagai wahana untuk meningkatkan pendapatan, terutama sebagai industri dan penghasil devisa dalam arti ekonomi sentris dan berorientasi pertumbuhan, sedangkan kebudayaan justru lebih bersifat konsumtif pengeluaran biaya. Apabila dipandang bagian per bagian maka antara kebudayaan dan pariwisata saling bertentangan namun dalam tujuan secara menyeluruh keduanya merupakan pisau bermata dua yang bermanfaat bagi pembangunan. Dalam hal ini juga sudah diatur dalam kode etik pariwisata dunia pasal 4 ayat 3 menyebutkan bahwa "Sumber penghasilan yang diperoleh dari wisatawan ke tempat wisata budaya dan monumen-monumen harus digunakan setidak-tidaknya sebagian bagi pemeliharaan, pelestarian, pengembangan dan memperkaya warisan budaya" Mowforth dan Maunt (dalam Siswanto, 2007: 168) menyatakan bahwa pariwisata harus "dimanusiakan", tidak hanya didorong oleh kekuatan pasar dan keuntungan semata-mata. Partisipasi masyarakat 
setempat dan upaya memasukkan budaya dan tradisi mereka dalam perencanaan pariwisata akan menimbulkan respek atau kebanggaan individu maupun masyarakat dari budaya tersebut.

Perlu ditekankan bahwa wisatawan yang berbasis budaya merupakan potensi yang cukup menjanjikan, sebagaimana pendapat Hughes (2002:164) yang menjelaskan bahwa "Typically well educated, affluent and broadly travelled, [and] they generally represent a highly desirable type of upscale visitor". Pada umumnya sepakat bahwa wisatawan budaya menghabiskan jauh lebih banyak kegiatan daripada wisatawan biasa, selanjutnya wisatawan budaya mengharapkan pengalaman yang berbeda dari liburan mereka dan harapan ini menjadi hari yang lebih penting dari hari ke hari. Selama pengalaman ini wisatawan dapat berinteraksi dengan tiga jenis atribut budaya; fisik (misalnya, dibangun warisan), umum (kehidupan sehari-hari masyarakat setempat), dan kegiatan budaya spesifik masyarakat setempat (misalnya, ritual dan festival).

Idealnya perkembangan pariwisata harus merujuk pada nilai-nilai dasar budaya di mana ini dibutuhkan bukan saja untuk eksistensi namun bisa dipadukan dengan penciptaan brand image dari karakteristik atau ciri khas daerah wisata Kota Bandung. Pola-pola pada ekonomi memang telah mengubah pemanfaatan budaya Sunda dalam perspektif pariwisata Kota Bandung. Perkembangan yang paling kontemporer di mana kebudayaan Sunda kini banyak mendapat pertanyaan seputar eksistensi kebudayaan Sunda yang sering kali mencuat ke permukaan di mana ini merupakan permasalahan yang subtansial terhadap peran dan eksistensi budaya terhadap perkembangan pariwisata di Kota Bandung.

Permasalahan ini menggambarkan bahwa terjadi pergeseran dari pemanfaatan pariwisata di mana nilai-nilai budaya Sunda tidak dipandang sebagai aspek yang dapat dimanfaatkan. Masalah ini diperparah dengan minimnya pagelaran budaya pada acara-acara yang besar, bahkan yang terjadi ketika hiburan budaya Sunda yang indetik dengan hiburan masyarakat Bandung kian memudar disebabkan konsep hiburan organ tunggal yang dewasa ini lebih diminati pada acaraacara tersebut.

Berbagai fenomena dari dampak perkembangan sektor pariwisata ekonomi terhadap pelunturan budaya, memposisikan bagaimana eksistensi budaya Sunda di masa depan. Berdasarkan uraian tersebut peneliti tertarik untuk meneliti lebih dalam dengan melihat beberapa aspek dari dampak perkembangan pariwisata terhadap eksistensi budaya Sunda di Kota Bandung. Tujuan penulisan ini untuk mengetahui, menganalisis, dan mendeskripsikan dampak perkembangan pariwisata terhadap eksistensi budaya Sunda di Kota Bandung.

\section{B. METO DE PEN ELITIA N}

Pendekatan yang digunakan dalam penelitian ini adalah deskriptif analisis dengan metode penelitian kualitatif, adapun penelitian kualitatif sebagaimana pendapat Cresswell (2004: 9) adalah "A qualitative study is defined as an inquiry process of understanding a social or human problem, based on building a complex holistic picture, formed with words, reporting detailed views of informants, and conducted in natural setting". Studi kualitatif dalam penelitian ini berhubungan dengan proses penyelidikan untuk memahami masalah sosial atau manusia, berdasarkan membangun gambaran holistik kompleks, dibentuk dengan kata-kata dan melaporkan pandangan rinci dari informan dan dilakukan dengan pengaturan alamiah pada melunturnya pariwisata berbasis budaya Sunda. Selanjutnya pendekatan kualitatif digunakan karena perumusan gejala-gejala, informasi-informasi atau keteranganketerangan mengenai implikasi perkembangan pariwisata yang tidak merujuk pada pelestarian budaya Sunda di Kota Bandung. Dengan demikian dalam 
penelitian ini, peneliti ingin menggambarkan suatu realitas mengenai dasar dari perkembangan pariwisata tersebut yang kurang merujuk pada sektor ekonomi dengan eksistensi nilai budaya Sunda. Maka jenis penelitian yang paling tepat adalah jenis kualitatif dengan metode deskriptif.

Pada penelitian jenis kualitatif ini peneliti berusaha mengembangkan konsep dan menghimpun fakta dengan cermat tanpa berusaha melakukan hipotesis mengenai apa saja dampak perkembangan pariwisata terhadap eksistensi budaya Sunda di Kota Bandung. Sedangkan penelitian deskriptif bertujuan untuk menggambarkan sejauhmana dampak perkembangan pariwisata terhadap eksistensi budaya Sunda di Kota Bandung yang kompleks dengan menerapkan konsepkonsep yang telah dikembangkan dalam penelitian ini.

Teknik pengumpulan data dalam penelitian ini terdiri atas observasi, kajian dokumentasi dan wawancara. Adapun berikut ini merupakan penjelasan teknik pengumpulan data tersebut:

1. Observasi

Observasi dapat diartikan sebagai pengamatan dan pencatatan secara sistematis terhadap gejala yang dapat diartikan sebagai pengamatan dan pencatatan secara sistematis terhadap gejala yang tampak pada objek penelitian. Metode ini dilakukan dengan cara mengamati secara langsung tentang kondisi yang terjadi selama di lapangan, baik berupa keadaan fisik maupun perilaku yang terjadi selama berlangsungnya penelitian. Adapun pengamatan dalam penelitian ini yaitu dampak perkembangan pariwisata terhadap eksistensi budaya Sunda di Kota Bandung di mana data diperoleh melalui pengamatan dicatat atau direkam dengan menggunakan alat yang tersedia seperti alat tulis, recorder dan kamera foto.

2.Kajian Dokumentasi

Kajian dokumentasi merupakan bagian dalam penelitian ini yang mempelajari sejumlah dokumen, peraturan perundang-undangan, laporan, buku-buku ilmiah, jurnal, arsip, foto-foto, dan bahan-bahan lain yang relevan dengan penelitian dan dianggap dapat dijadikan sebagai sumber data. Dalam penelitian ini, peneliti menggunakan data Badan Pusat Statitik dan beberapa literatur yang relevan dalam penelitian ini.

\section{Wawancara}

Wawancara adalah percakapan dengan maksud tertentu yang dilakukan oleh dua pihak yaitu pewawancara yang mengajukan pertanyaan dan yang diwawancarai memberikan jawaban atas pertanyaan itu. Wawancara juga merupakan alat pengumpulan data atau informasi, dengan cara mengajukan sejumlah pertanyaan secara lisan untuk dijawab secara lisan pula oleh responden. Dalam penelitian ini wawancara berisikan pertanyaanpertanyaan yang berhubungan dengan dampak perkembangan pariwisata terhadap eksistensi budaya Sunda di Kota Bandung. Adapun informan dalam penelitian ini sebagian masyarakat dan wisatawan yang terdapat di Kota Bandung.

Verifikasi data diperlukan bagi setiap hasil penelitian. Dalam penelitian kualitatif standar tersebut dinamakan keabsahan data. Moleong (2002:121) menyebutkan bahwa untuk menetapkan keabsahan (trustworthiness) data diperlukan tehnik pemeriksaan. Salah satu keabsahan adalah credibility (derajat kepercayaan). Kriteria ini pada dasarnya menggantikan konsep validitas internal dari nonkualitatif. Kriteria ini berfungsi untuk melaksanakan inquiry (penyelidikan) sedemikian rupa sehingga tingkat penemuannya dapat dicapai dan menunjukkan derajat kepercayaan hasilhasil penemuan dengan jalan pembuktian. Kegiatan yang akan dilakukan untuk memeriksa kredibilitas hasil penelitian adalah sebagai berikut :

1. Membicarakan dengan orang lain (Peer Debriefing). Sebagai usaha 
untuk memenuhi derajat kepercayaan dengan membicarakan dengan orang lain yang mempunyai pengetahuan tentang pokok penelitian dan juga tentang penelitian kualitatif. Pembicaraan ini bertujuan untuk memperoleh kritik, pertanyaan-pertanyaan yang tajam dan menantang tingkat kepercayaan akan keberhasilan penelitian. Kegiatan yang dilakukan dalam rangka peer debriefing, yaitu melakukan diskusi dengan beberapa ahli yang relevan dalam penelitian ini.

2. Triangulasi Data

Dalam penelitian ini, penulis menggunakan metode triangulasi data untuk menguji validitas data dilakukan dengan mengecek data pada sumber yang sama dengan teknik yang berbeda, yaitu dengan cara data diperoleh dari wawancara, lalu dicek dengan observasi dan dengan dokumentasi sehingga uji kredibilitas data yang diperoleh dengan tiga teknik pengujian data tersebut tidak menghasilkan data yang berbeda di lapangan.

Tabel 1. Jenis Objek Wisata dan Jumlah Wisatawan di Kota Bandung

\begin{tabular}{|c|c|c|c|}
\hline \multirow{2}{*}{$\begin{array}{l}\text { Jenis Objek } \\
\text { Wisata }\end{array}$} & \multicolumn{3}{|c|}{ Wisatawan } \\
\hline & Wisnus & Wisman & Jumlah \\
\hline $\begin{array}{l}\text { Kebun } \\
\text { Binatang } \\
\text { Bandung }\end{array}$ & 1.271 .702 & - & 1.271 .702 \\
\hline $\begin{array}{l}\text { Taman Lalu } \\
\text { Lintas AISN }\end{array}$ & 250.833 & - & 250.833 \\
\hline $\begin{array}{l}\text { Karang } \\
\text { Setra }\end{array}$ & 80.488 & - & 80.488 \\
\hline $\begin{array}{l}\text { Museum } \\
\text { Geologi }\end{array}$ & 436.869 & 3.574 & 440.443 \\
\hline $\begin{array}{l}\text { Museum Pos } \\
\text { Indonesia }\end{array}$ & 35.180 & 170 & 35.350 \\
\hline $\begin{array}{l}\text { Museum } \\
\text { Konfrensi } \\
\text { Asia Afrika }\end{array}$ & 140.342 & 5.623 & 145.965 \\
\hline $\begin{array}{l}\text { Museum } \\
\text { Mandala } \\
\text { Wangsit } \\
\text { Siliwangi }\end{array}$ & 6.706 & 76 & 6.782 \\
\hline $\begin{array}{l}\text { Museum Sri } \\
\text { Baduga }\end{array}$ & 178.068 & 809 & 178.887 \\
\hline $\begin{array}{l}\text { Saung Ang- } \\
\text { klung Ujo }\end{array}$ & 86.096 & 18.675 & 104.771 \\
\hline
\end{tabular}

Sumber: BPS, 2014
3. Mengadakan members chek

Proses ini dilakukan pada akhir wawancara dengan mengecek ulang secara garis besar berbagai hal yang telah disampaikan oleh informan yang telah diperoleh dan digunakan dalam penulisan laporan penelitian sesuai dengan apa yang dimaksud oleh informan. Kegiatan ini dilakukan dengam memadukan beberapa hasil wawancara serta mengamati kesesuaian hasil wawancara dengan dokumen dan fakta di lapangan.

\section{HASIL DAN BAHASAN}

Pariwisata di suatu daerah sebagaimana Kota Bandung merupakan sektor yang akan terus berkembang, hal ini didasarkan pada semakin majunya pemikiran manusia dalam menciptakan dan memenuhi kebutuhan pariwisatanya. Konsep yang terus berkembang ketika para wisatawan menginginkan pariwisata yang lebih menempatkan perjalanan gaya hidup, maksudnya adalah para wisatawan mengutamakan pariwisata yang searah dengan perkembangan zaman di mana kebutuhan ini bukan saja memenuhi liburan namun dapat memenuhi kebutuhan material kehidupannya. Pada sisi lain, sistem pariwisata berbasis kreatif terus berkembang di Kota Bandung sebagai pengakomodiran perkembangan tersebut melalui penciptaan barang-barang yang dicari dan dibutuhkan oleh para wisatawan.

Perkembangan pola-pola pariwisata ini pada kenyataanya terus menunjukkan nilai-nilainya sehingga mengubah perspektif para wisatawan dan pengusaha terhadap potensi pariwisata di Kota Bandung, bahkan wisata kreatif berbasis ekonomi matrial terus menunjukkan kontribusinya dalam menarik wisata yang berada di luar Kota Bandung. Untuk lebih jelasnya berikut ini perkembangan pariwisata berdasarkan jumlah pengunjung pada objek wisata di Kota Bandung:

Cukup dilematis memang ketika pariwisata ekonomi kreatif, alam dan sejarah lebih berkembang daripada 
pariwisata yang mencerminkan budaya. Bahkan sebagaimana hasil wawancara bahwa wisatawan ternyata lebih familiar dengan tempat pariwisata belanja dan kuliner disebabkan infrastruktur pariwisata ini tersedia di sudut Kota Bandung. Fenomena ini sebagaimana apa yang dikatkan oleh Jensen (dalam Gezici dan Kerimoglu, 2010: 253) yang menjelaskan bahwa "....While culture-led regeneration projects try to reconstruct the urban economy and image, they often give importance to economic development goals, property development, and urban entrepreneurialism, rather than to the quality of life goals, the protection of local identities, social justice or inclusion". Pada proyek-proyek regenerasi budaya yang dipimpin mencoba untuk merekonstruksi perekonomian dan citra perkotaan, mereka sering memberikan pentingnya tujuan-tujuan pembangunan ekonomi, pengembangan properti dan wirausaha perkotaan, daripada kualitas tujuan hidup, perlindungan identitas lokal, keadilan sosial atau inklusi.

Pada pola peningkatan pariwisata memang dapat dilakukan dengan cara yang kompleks, di mana ini akan menyediakan berbagai pilihan bagi para turis untuk berkunjung. Namun, tentunya pariwisata tersebut harus berjalan dengan seimbang. Keseimbangan terwujud ketika pariwisata sebagai kegiatan ekonomi harus didasarkan juga pada kegiatan-kegiatan yang menjaga eksistensi budaya Sunda yang sudah lama melekat terhadap masyarakat Bandung. Konsep ideal ini kian tidak seimbang ketika para wisatawan yang datang kurang melihat nilai budaya Sunda sebagaimana identitas Kota Bandung yang dapat berguna bagi pelestarian budaya. Mereka lebih memilih pariwisata yang menawarkan produk-produk pakaian, makanan, tempat wisata modern sampai dengan menikmati alam Kota Bandung.

Berbagai permasalahan tersebut menjelaskan bahwa perkembangan pariwisata di Kota Bandung pada realitasnya berdampak pada melunturnya pariwisata bernuansa nilai budaya Sunda, eksistensi budaya Sunda sebagai nilai-nilai yang harus dilestarikan kian kurang dihornati pada sisi esensi sejarah. Hal ini ditandai ketika beberapa pagelaran kesenian Sunda tidak lagi menyentuh pemahaman pada nilai-nilai yang terkandung pada budaya Sunda, pagelaran hanya bersifat formalitas dan seremonial serta bermotif ekonomi. Tidak heran ketika dalam perkembangan pariwisata di Kota Bandung, nilai-nilai budaya masih terbelenggu pada paradigma generasi muda yang kurang melihat pada pentingnya nilai budaya pada suatu pergaulan sosial pariwisata.

Kurang digunakan nilai-nilai budaya Sunda dalam pariwisata sebagaimana "silih asih, silih asah, dan silih asuh" (saling mengasihi, saling mempertajam diri, dan saling memelihara dan melindungi), merupakan ciri budaya Sunda yang menunjukkan karakter yang khas dari budaya religius Sunda sebagai konsekuensi dari pandangan hidup keagamaannya. Penggunaan "silih asih, silih asah, dan silih asuh" adalah wujud interaksi religius sosial yang menekankan sapaan cinta kasih Sang Pencipta dan merespons cinta kasih Sang Pencipta tersebut melalui cinta kasih kepada sesama manusia. Dengan ungkapan lain, saling asih merupakan kualitas interaksi yang memegang teguh nilai-nilai ketuhanan dan nilai-nilai kemanusiaan. Konsepsi ini pada idealnya dapat dimanfaatkan terhadap sosialasi nilai budaya dalam pariwisata di Kota Bandung. Bahkan jika menelusuri arti dari nilai-nilai budaya tersebut, wisatawan tentunya akan tertarik untuk menelusuri lebih dalam mengenai karakteristik budaya Sunda.

Semangat ketuhanan dan kemanusiaan inilah yang kemudian melahirkan dan memunculkan moralitas egaliter (persamaan) dalam sebagian masyarakat Kota Bandung. Dalam tradisi masyarakat Sunda, manusia tentunya saling menghormati di mana dalam budaya Sunda tidak ada manusia yang dipandang superior maupun inferior sebab menentang 
semangat ketuhanan dan semangat kemanusiaan. Mendudukkan manusia pada kedudukan superior atau inferior merupakan praktik dari syirik sosial. Ketika ada manusia yang dianggap superior (tinggi), berarti mendudukkan manusia sejajar dengan Tuhan dan jika mendudukkan manusia pada kedudukan yang inferior (rendah), berarti mengangkat dirinya sejajar dengan Tuhan. Dalam masyarakat Sunda "silih asih, silih asah, dan silih asuh" manusia didudukkan secara sejajar (egaliter) satu sama lainnya. Prinsip egaliter ini kemudian melahirkan etos musyawarah, ta'awun (kerjasama) dan sikap untuk senantiasa bertindak adil dalam masyarakat Sunda. Etos dan moralitas inilah yang menjadikan masyarakat teratur, dinamis dan harmonis.

Dalam penggunaan pengelaborasi kebudayaan Sunda kontemporer setidaknya ada empat daya hidup yang perlu dicermati dalam kebudayaan Sunda yang dapat dimanfaatkan pada sektor wisata, yaitu, kemampuan beradaptasi, kemampuan mobilitas, kemampuan tumbuh dan berkembang, serta kemampuan regenerasi. Kemampuan beradaptasi kebudayaan Sunda terutama dalam merespon berbagai tantangan yang muncul, baik dari dalam maupun dari luar, dapat dikatakan memperlihatkan tampilan yang kurang begitu menggembirakan. Bahkan kebudayaan Sunda seperti tidak memiliki daya hidup manakala berhadapan dengan tantangan dari luar. Akibatnya, tidaklah mengherankan bila semakin lama semakin banyak unsur kebudayaan Sunda yang tergilas oleh kebudayaan asing (Dienaputra, 2003: 6). Permasalah ini tentu mengakibatkan budaya Sunda pada posisi lemah, dimana ini disebabkan oleh aspek dari pola masyarakat yang kurang berkontribusi dalam pelestarian budaya Sunda melalui pariwisata.

Apabila kemampuan beradaptasi kebudayaan Sunda dalam pariwisata memperlihatkan tampilan yang kurang begitu menggembirakan maka hal itu sejalan pula dengan kemampuan mobilitasnya. Kemampuan kebudayaan Sunda untuk melakukan mobilitas, baik vertikal maupun horizontal, dapat dikatakan sangat lemah. Oleh karenanya, jangankan di luar komunitas Sunda, di dalam komunitas Sunda sendiri, kebudayaan Sunda seringkali menjadi tampak asing. Meskipun ada unsur kebudayaan Sunda yang memperlihatkan kemampuan untuk bermobilitas, baik secara horisontal maupun vertikal, tetapi secara umum kemampuan kebudayaan Sunda untuk bermobilitas dapat dikatakan masih rendah. Akibatnya pariwisata kebudayaan Sunda tidak saja tampak jalan di tempat tetapi juga berjalan mundur dan potensi ini kurang dimanfaatkan oleh masyarakat (Dienaputra, 2003: 7).

Sebagaimana diketahui bahwa tantangan yang dihadapi dalam pembangunan kebudayaan pada dasarnya masih tingginya sifat materialisme di masyarakat yang mulai meninggalkan nilai-nilai luhur budaya Sunda serta menurunnya akhlak moralitas pada sebagian masyarakat. Di samping itu permasalahan yang mendesak dalam pembangunan pariwisata kebudayaan di Kota Bandung adalah adanya kecenderungan semakin menurunnya tingkat pengelolaan aset-aset budaya baik yang bersifat fisik dan nonfisik. Pengelolaan yang masih lemah terhadap aset dan pemahaman keragamaan budaya Sunda terlihat belum adanya kriteria yang jelas dalam pengamanan aset kebudayaan terutama aset kebudayaan yang berskala daerah. Ketidakjelasan tersebut tercermin dari kekurangpedulian terhadap keberadaan aset budaya dalam rencana pembangunan pariwisata secara komprehensif di Kota Bandung.

Permasalahan lain muncul ketika aspek aktualisasi budaya lokal dalam kehidupan bermasyarakat pada kenyataannya masih belum berjalan dengan baik, hal ini dapat dilihat pada nilai budaya yang bersumber pada kearifan lokal dan kebudayaan Sunda dengan masuknya unsur-unsur budaya yang merugikan yang 
diserap tanpa filter budaya yang jelas. Adapun ini menyebabkan masyarakat cenderung tidak lagi menggunakan nilainilai budaya tersebut dalam kehidupan, sehingga tidak ada lagi pilihan selain terjun dalam kancah pergaulan dan interaksi kebudayaan lintas bangsa. Kenyataan ini berimplikasi pada penggunaan nilai-nilai budaya Sunda dari masyarakatnya tidak begitu terlihat, khususnya pada sisi kontribusinya dalam menjadikan budaya Sunda sebagai arsitektur nilai dalam meningkatkan kunjungan pariwisata.

Selanjutnya berdasarkan hasil penelitian menunjukkan terdapat beberapa persoalan di Kota Bandung khususnya pada budaya dan pariwisata. Adapun temuan permasalahan tersebut meliputi; (1) Kurang terdapatnya sinergiritas antara aktor/pelaku pariwisata; (2) Kurang berkembangnya pengembangan sumber daya sebagai perilaku aktor pariwisata dalam proses rekayasa produk seni dan pariwisata; (3) Masih minimnya kompetensi aktor dalam mengelola budaya dan pariwisata daerah terhadap pelayanan yang berstandar nasional, bahkan internasional; (4) Pengembangan produk budaya dan pariwisata, masih mengandalkan pada sektor unggulan, di mana ini akan rentan hilangnya budaya-budaya yang tidak terlalu dikenal oleh masyarakat.

Gejala pariwisata sesungguhnya tidak terlepas dari kebudayaan sebuah masyarakat. Dengan demikian dalam kunjungan wisata, paling tidak terjadi kontak dan interaksi kebudayaan wisatawan dengan kebudayaan penduduk setempat. Ketika seorang berkunjung ke suatu daerah yang lebih baik dari kebudayaannya, ia memiliki kesempatan mengalami perjalanan yang dapat meningkatkan kebudayaan miliknya sendiri. Kalaupun wisatawan berkunjung ke tempat yang lebih jelek, maka wisatawan mendapatkan kesempatan melihat dan mengalami hal yang jelek tersebut. Oleh karena itu, citra suatu pariwisata dalam benak wisatawan akan memiliki pengaruh yang besar terhadap kunjungan wisatawan di masa yang akan datang.

Konteks kebudayaan dalam kawasan wisata budaya diuraikan berdasarkan pentingnya pelestarian budaya. Uraian di bawah ini akan menjelaskan karakteristik atau bentuk kebudayaan dan usaha pelestarian kebudayaan. Koentjaraningrat (1987:12) menjelaskan bahwa terdapat karakteristik atau bentuk kebudayaan merupakan suatu unsur-unsur yang universal. Unsur-unsur kebudayaan tersebut sebagai berikut:

1. Sistem religi dan upacara keagamaan, yaitu sistem kepercayaan dengan segala bentuk pelaksanaannya dalam kehidupan sehari-hari.

2. Sistem dan organisasi kemasyarakatan, yaitu adanya tatanan masyarakat yang mempunyai pola hubungan tertentu.

3. Sistem pengetahuan, yaitu hasil daya cipta, karya dan karsa manusia.

4. Bahasa, yaitu alat komunikasi yang digunakan golongan masyarakat.

5. Kesenian, yaitu berbagai bentuk produk seni.

6. Sistem mata pencaharian hidup, yaitu sistem pemenuhan kebutuhan hidup masyarakat.

7. Sistem teknologi dan peralatan, yaitu produk ciptaan manusia berdasarkan ilmu.

Berdasarkan unsur-unsur tersebut, pada prinsipnya kebudayaan dalam konteks pariwisata semestinya memiliki peran yang cukup setidaknya dalam hal eksistensi (nonekonomi), namun prinsip ini tidak terlalu berkembang. Kenyataan yang terjadi ketika prinsip ekonomi terus berkembang tanpa pemisahan yang jelas di antara nilai-nilai budaya Sunda. Secara ideal, peningkatan pariwisata memiliki beberapa elemen kebudayaan dan peristiwa kebudayaan, antara lain; (1) Sebagai sarana dan media promosi kepariwisataan baik yang langsung di dalam maupun di luar negeri; (2) sebagai atraksi yang mencakup pertunjukan kesenian, pameran kesenian; dan (3) sebagai objek wisata dengan aneka ragam corak khas. 
Perencanaan dan pengembangan kawasan wisata budaya di Kota Bandung merupakan salah satu bentuk konkret dari upaya pelestarian budaya dan manfaat bagi pengembangan kepariwisataan baik itu yang mengandung nilai-nilai pelestarian aset budaya, agar aset budaya tersebut dapat berfungsi lebih maksimal untuk peningkatan dan pemahaman masyarakat Kota Bandung akan pentingnya karyakarya budaya bangsa dalam bentuk manajemen pengelolaan kebudayaan dan kepariwisataan. Kawasan wisata budaya pada dasarnya memiliki makna dan arti sebagaimana penguatan regulasi dan penyusunan fondasi kebijakan yang mempermudah dan menjamin aktor/pelaku di bidang kebudayaan dan kepariwisataan bersinergi dan berkoordinasi. Kawasan wisata budaya merupakan implementasi yang didasari pada dua kepentingan yaitu mengembangkan kebudayaan di mana kebudayaan tersebut merupakan bagian penting dalam menumbuhkembangkan budaya lokal yang memiliki nilai unique selling point sebagai dasar dalam memasyarakatkan keunggulan komparatif dari segi budaya dan kepariwisataan.

Pengembangan pariwisata harus merupakan pengembangan yang berencana secara menyeluruh, sehingga dapat diperoleh manfaat yang optimal bagi masyarakat Kota Bandung baik dari segi ekonomi, sosial dan kultural. Perencanaan ini harus mengintegrasikan pengembangan pariwisata ke dalam suatu program pembangunan ekonomi, fisik, dan sosial dari karakteristik Kota Bandung, ini akan berfungsi pada adanya karakteristik yang hanya dimiliki Kota Bandung. Di samping itu, rencana tersebut harus mampu memberikan kerangka kerja kebijakan pemerintah Kota Bandung untuk mendorong dan mengendalikan pengembangan pariwisata berbasis budaya lokal. Peranan pemerintah dalam mengembangkan pariwisata dalam garis besarnya adalah menyediakan infrastuktur (tidak hanya dalam bentuk fisik), memperluas berbagai bentuk fasilitas, kegiatan koordinasi antara aparatur pemerintah dengan pihak swasta, pengaturan dan promosi umum ke luar negeri. Tidak dapat dipungkiri bahwa hampir di seluruh daerah Indonesia terdapat potensi pariwisata, maka yang perlu diperhatikan adalah sarana transportasi, keadaan infrasruktur dan sarana-sarana pariwisata.

Pengelolaan kebudayaan dan kepariwisataan pada satu kawasan merupakan upaya dalam mensinergiskan berbagai kepentingan sebagaimana makna dari suatu kawasan merupakan keterpaduan pengelolaan yang memiliki nilai promosi, yaitu one stop service, esensinya pada satu tempat dapat diberikan pelayanan dari berbagai jasa usaha pariwisata dan dapat menikmati berbagai sajian kesenian dan kawasan wisata budaya, mencerminkan pengelolaan wisata budaya secara terpadu untuk tercapainya optimalisasi aset kepariwisataan dan kebudayaan sebagai langkah pemberdayaan masyarakat lokal yang sejalan dengan perkembangan wisata yang maju di Kota Bandung.

Selanjutnya konsep dalam mempertahankan eksistensi budaya Sunda yaitu dengam memberikan paket wisatawan yang lebih kompleks, maksudnya adalah pariwisata budaya yang disajikan harus dikemas sedemikian rupa sehingga dapat dikonsumsi oleh para wisatawan. Adapun konsep itu berdasarkan Bob (1993: 12) yang menjelaskan bahwa "Tourism, especially many forms of 'cultural' and 'environmental' tourism, is entertainment, striving to satisfy tourists' needs, wants and demands. To be successful and, therefore, commercially viable, the tourism product must be manipulated and packaged in such a way that it can easily consumed by the public." Pariwisata, terutama banyak bentuk pariwisata budaya dan lingkungan adalah hiburan, berjuang untuk memenuhi kebutuhan keinginan dan tuntutan turis. Untuk itu produk pariwisata harus dimanipulasi dan dikemas 
sedemikian rupa sehingga dapat dengan mudah dikonsumsi oleh publik.

Pariwisata dewasa ini bukan hanya sekedar pergerakan wisatawan dari satu negara ke negara lain tetapi lebih dipandang pada perpindahan komunitas massa yang mengikutinya dan dampaknya pada masyarakat tradisional setempat. Realitas ini merupakan salah satu dari banyaknya dampak negatif. Dampak negatif ini disebabkan karena kurangnya perhatian yang diberikan pada persyaratan yang diperlukan bagi pariwisata yang berkesinambungan. Pembangunan pariwisata budaya tanpa merusak budaya setempat hanya dapat dicapai dengan jika antara berbagai pihak seperti pemerintah, sektor swasta dan masyarakat bekerja bahu membahu untuk mencapai tujuan bersama dalam pemanfaatan perkembangan pariwisata dalam mempertahankan eksistensi budaya Sunda di Kota Bandung.

Untuk membangun hubungan yang kuat antara pariwisata dan budaya maka perlindungan harus menjadi cara hidup atau gaya hidup, hal tersebut dari masyarakat dan kebudayaan di Kota Bandung. Jika hubungan yang kuat tetap ada di skala lokal dan menyebarkan kebudayaan yang berorientasi pada negara, kemudian para turis juga didorong untuk memasuki garis untuk melihat dan menikmati namun tidak merusak karena telah mempunyai bekal pengetahuan tentang nilai-nilai luhurnya.

Pada sisi ini pemerintah bersama masyarakat dalam memprogramkan sesuatu yang konkrit harus memiliki tujuan yang jelas dalam upaya pelestarian aset budaya, agar aset tersebut mengandung nilai-nilai positif sebagai sarana edukatif kultural, pariwisata dan pengembangan kebudayaan yang dapat berfungsi optimal untuk peningkatan pemahaman peradaban dan kesejahteraan masyarakat. Bentuk konkrit melalui penggunaan teknologi informasi sebagai sarana pengenalan, pendidikan, serta sarana promosi merupakan alternatif yang tepat untuk meninggalkan kesan kinerja manajeman pariwisata yang selama ini tidak seimbang terhadap penggunaan budaya Sunda.

Era globalisasi khususnya dalam penyebaran informasi di mana jarak antarnegara semakin menyempit, dimana ini mendeskripsikan arus informasi antar negara di dunia semakin cepat dan terbuka, maka kenyataan ini pada prinsipnya akan berdampak terhadap masuknya budaya dari luar dan mengganggu budaya Sunda yang telah ada. Akar budaya Sunda yang digali berabad-abad dari bangsa sendiri yang memiliki nilai-nilai luhur budaya bangsa tentunya perlu dilestarikan, terutama budaya-budaya lokal yang bersifat nonbendawi (intangible). Kekhawatiran banyak orang akan dampak negatif pengembangan pariwisata terhadap eksistensi kebudayaan dapat dimengerti karena banyak orang beranggapan bahwa suatu kebudayaan itu akan lestari kalau tidak tersentuh oleh pengaruh kebudayaan lain. Asumsi itu sama sekali tidak benar, karena kebudayaan yang terisolir itu tetap akan mengalami perkembangan walaupun lamban. Pergantian generasi dan perubahan lingkungan akan merangsang penduduk untuk mengembangkan kebudayaan sesuai dengan kemampuan mereka menangkap dan memahami tantangan yang mereka hadapi. Dengan demikian, lambat atau cepat setiap kebudayaan akan mengalami perkembangan. Sedang pengaruh dari luar akan mempercepat perkembangan kebudayaan dengan melalui proses akulturasi dan dimungkinkan eksistensi budaya lama akan bergeser pada eksitensi budaya baru.

Dinamika budaya mampu mengembangkan dirinya sehingga modernitas dan tradisi menyatu dalam tiap tahap memberi stabilitas yang mantap dan juga meningkatkan kepercayaan pada diri sendiri serta membuatnya gairah pada realitasnya tidak sama sekali menunjukkan eksistensinya. Ini merupakan dampak dari perkembangan pariwisata yang tidak merujuk pada konsepsi yang lebih luas, hal yang terjadi ketika pariwisata berkembang dengan motif dan ekonominya masing- 
masing. Hal ini akan berdampak pada kebudayaan yang tidak berjalan bersama. Ini memperlihatkan bahwa budaya akan terus berkembang sebagai akibat kemajuan-kemajuan masyarakat itu sendiri, menuju masyarakat yang modern dengan kehilangan dirinya (budaya asli). Pengembangan kebudayaan memang dibutuhkan oleh masyarakat sedangkan pariwisata memberi dukungan terhadap pengembangan kebudayaan dan mendorong munculnya kreativitas pada masyarakat Bandung. Munculnya krea-tivitas telah mendorong pengembangan kebudayaan. Pengembangan kebudayaan melalui penggalian-penggalian kebudayaan itu sendiri menimbulkan pemahaman dan kesadaran akan kebudayaan menumbuhkan keyakinan pada kemampuan diri sendiri dan sadar berbudaya.

\section{PEN UTUP}

Sebagai salah satu destinasi wisata yang terus berkembang, Kota Bandung merupakan daerah yang sebenarnya memiliki karakteristik pariwisata dalam sisi nilai budaya Sunda. Pariwisata yang membuat kebudayaan harus selalu mengalami pertemuan-pertemuan dengan berbagai kebudayaan, maka pembinaan kebudayaan lokal harus dilakukan secara terus menerus. Kesepakatan yang lebih penting, jangan sampai terdapat gejala budaya asli lokal Sunda diasingkan dari lingkungan kebudayaannya sendiri. Karena hal ini akan dapat membawa akibat buruk, seperti misalnya terjadi erosi kebudayaan yang dipaksa oleh kemiskinan penduduknya. Tiap-tiap program pembangunan hendaknya selalu berkaitan dengan potensi dasar yang dimiliki oleh masyarakat lokal, yakni kebudayaan yang bernapaskan nilainilai budaya.

Berdasarkan hasil penelitian dapat diketahui bahwa berkembangnya pariwisata di Kota Bandung dapat meningkatkan nilai-nilai ekonomi masyarakat, namun di sisi lain menunjukkan bahwa perkembangan pariwisata di Kota Bandung kurang merujuk pada pemanfaatan budaya-budaya lokal sebagaimana budaya Sunda, hal ini akan memengaruhi eksistensi budaya Sunda sebagai sektor andalan Kota Bandung. Pelunturan budaya Sunda dalam pengembangan dan pemanfaatan potensi pariwisata pada kenyataannya masih tersendat pada infrastuktur dan ketidakjelasan konsep perencanaan dan pengembangan.

Rekomendasi dalam kajian ini yaitu harus dilakukan koordinasi konstrutktif antaraktor yang berkaitan dengan pariwisata sehingga potensi pelestarian budaya Sunda dapat dioptimalkan. Adapun cara tersebut dibuat melalui lembaga bersama dalam merencanakan berbagai strategi potensi dari kegiatan pariwisata dalam meningkatkan eksistensi budaya Sunda di Kota Bandung.

\section{DAFTAR SU MBER}

Badan Pusat Statistik, Berita Resmi Statistik: Perkembangan Pariwisata dan Transportasi Nasional Desember 2013. No. 12/02/Th. XVII, 3 Februari 2014. Jakarta: BPS.

Bob, Charles. 1993.

Some Fundamental Truths About Tourism: 7 Understanding Tourism's Social and Environmen fall lmpacs, Journal Of Sustainable Tourism Vol. 1, No.1, 1993.

Chancharat, Surachai. 2011. Thai Tourism and Economic Development: The Current State of Research. Journal Kasetsart J. (Soc. Sci) $32: 340-351$.

Creswell John, W. 2004.

Research Design: Qualitative, Quantitative, and Mixed Methods Approaches. London: SAGE Publi-cations.

Dienaputra, Reiza D. 2003.

Kebudayaan Sunda: Antara Mitos dan Realitas. Makalah disampaikan sebagai materi presentasi dalam Seminar Nasional, dengan tema,"Menggugat Budaya Sunda: Perspektif Periferal", yang diselenggarakan oleh Perhimpunan Mahasiswa Bogor Daerah Istimewa Yogyakarta (PAMOR RAYA), bertem- 
pat di Balai Utari Mandala Bhakti Wanitatama, Yogyakarta, 20 Oktober 2003.

Du Cros, H. 2001.

A New Model to Assist in Planning for Sustainable Cultural Heritage Tourism. International Journal of Tourism Research, 3(2), 165-170.

Gezici, Ferhan and Ebru Kerimoglu. 2011.

Culture, Tourism and Regeneration Process in Istanbul. International Journal of Culture, Tourism And Hospitality Research. Vol. 4 No. 32010 , pp. 252-265.

Hughes, H.L., 2002.

Culture and Tourism:a Framework for Further Analysis. Managing Leisure, 7, pp.164-175.

Jenkins, Carson L. 1998.

Tourism in Developing Countries: The Privatization Issue. Pp 3-9 in Tourism: The State of Art, ed. A. V. Seaton. Chichester: John Wiley \& Sons.

Koentjaraningrat. 1987.

Pengantar Ilmu Antropologi. Jakarta: Balai Pustaka

Liu, Yi-De dan Lin, Chi-Fan. 2011.

The Development of Cultural Tourism: A Review of UK Experience Tourismos: An International Multidisciplinary Journal Of Tourism Volume 6, Number 2, Autumn 2011, pp. 363-376.

Moleong, Lexy J. 2002. Metodologi Penelitian Kualitatif. Bandung: Rosda.

Petrevska, Biljana. 2012.

Tourism Contribution to Regional Development: Best Practice in Macedonia. Journal of Community Positive Practices 3/2012, pp 425-440.

Pitana dan Gayatri. 2005.

Sosiologi Pariwisata. Yogyakarta: Andi.

Sandeep, Kumar dan Vinod, Kumar. 2014. Perception of Socio-Culture Impacts of Tourism: A Sociological Review. International Research Journal of Social Sciences. Vol. 3(2), 40-43, February (2014).
Silberberg, T. 1995.

Cultural Tourism and Business Opportunities for Museums and Heritage Places. Tourism Management, 16(5), 361-365.

Siswanto. 2007.

"Pariwisata dan Pelestarian Warisan Budaya". Berkala Arkeologi Tahun XXVII Edisi No. 1 / Mei 2007. 